\title{
Biological screening of selected flora of Pakistan
}

\author{
M. Zia-Ul-Haq ${ }^{*}$, M. Raza Shah², Mughal Qayum³, Sezai Ercisli \\ ${ }^{1}$ Department of Pharmacognosy, University of Karachi, Karachi-75270, Pakistan \\ 2 H.E.J. Research Institute of Chemistry, International Center for Chemical and Biological Sciences, University of Karachi, Karachi-75270, Pakistan \\ ${ }^{3}$ Department of Pharmacy, Abdul Wali Khan University, Mardan-23200, Pakistan \\ ${ }^{4}$ Department of Horticulture, Ataturk University, Erzurum-25240, Turkey
}

\begin{abstract}
Methanolic extracts of different parts of five medicinal plants, Ferula assafoetida L. resin, Grewia asiatica L. leaves, Ipomoea hederacea Jacq. seeds, Lepidium sativum L. seeds and Terminalia chebula Retz. fruits were tested in vitro for their cytotoxic, phytotoxic, insecticidal, nematicidal and anthelmintic activities. Ipomoea hederacea showed very significant phytotoxic and cytotoxic activity, with $100 \%$ inhibition of Lemna minor growth and $100 \%$ death of Artemia salina at concentrations of 1000 and $100 \mu \mathrm{gL} \mathrm{m}^{-1}$. Grewia asiatica exhibited very weak activities while Lepidium sativum and Ferula assafoetida showed moderate to good potential in all three bioassays. The results suggest screening of Ipomoea hederacea seeds further for isolation of bioactive compounds that may be responsible for its toxic potential.
\end{abstract}

\section{INTRODUCTION}

Pakistan has varied geographic, climatic and vegetation features which are essential to the formation of one of the most diverse flora, which varies through latitudinal and longitudinal gradients. The country is characterized by a wide range of macrohabitats across elevation and climatic gradients, generating high environmental heterogeneity. Some important thematic areas of indigenous flora have been recently covered (Zia-Ul-Haq et al., 2009; 2010; 2011 a, b, c, d, e; 2012 a, b, c, d, e, f; Nisar et al., 2010 a, b, c; 2011), however most of medicinal flora of Pakistan remains unexplored. All plants may not be as useful as claimed, or may have more therapeutic properties than are known traditionally. Claimed therapeutic efficacies of medicinal plants are often criticized due to dearth of research, critical evaluation and in vivo studies, questioning the safety of their use. Therefore, proper scientific investigations are required to explore the exact medicinal potential of plants.

Ferula assafoetida L. (Umbelliferae), Grewia asiatica L. (Malvaceae), Ipomoea hederacea Jacq. (Convolvulaceae), Lepidium sativum L. (Brassicaceae), and Terminalia chebula Retz. (Combretaceae) are multi-purpose medicinal plants used in various parts of Pakistan. Ferula assafoetida resin is believed to possess sedative, expectorant, analgesic, carminative, stimulant, antiperiodic, antidiabetic, antispasmodic, emmenagogue, vermifuge, laxative, anti-inflammatory, contraceptive and antiepileptic properties (Zia-Ul-Haq et al., 2012d). Grewia asiatica is believed to possess antipyretic, antidiabetic, analgesic, antifertility, antibiotic and antimicrobial properties (Zia-Ul-Haq et al., 2012a). Ipomoea hederaceae seeds are diuretic, anthelmintic, a blood purifier, and are used for treatment of constipation, inflammations, abdominal diseases, fevers, headaches, bronchitis and dropsy (Nasir and Ali, 1979; Chopra et al. 1986; Joshi, 2000). Lepidum sativum seeds are used in chronic enlargement of liver and spleen. The bruised seeds mixed with lime juice are used as local application for the relief of inflammatory and rheumatic pains. The seeds are bitter, themogenic, depurative, rubefacient, galactagogue, emmenagogue, tonic, aphrodisiac and diuretic (Manohar et al., 2012). Terminalia chebula fruit is a mild laxative, stomachic, tonic and antispasmodic. It is useful in ophthalmia, hemorrhoids, dental caries, bleeding gums and oral cavity ulcers. Its paste with water is found to be anti-inflammatory, analgesic and to have purifying and healing capacity for wounds (Nadkarni, 1976). Besides their diverse and broad spectrum ethnopharmacological uses, all these plants have some common medicinal uses, since they all possess antimicrobial, antioxidant and anti-inflammatory potential.

Biological screening including cytotoxic, phytotoxic, insecticidal, nematicidal and anthelmintic activities is an important part of the development of new drugs from medicinal plants. These are low cost, quick, and easy benchtop general bioassays used for screening and monitoring of crude extracts of plants. To the best of our knowledge, no systematic investigation has been made on biological screening of the medicinal plants that we have selected. The current study has been designed to screen the methanolic extracts of selected plants for phytotoxicity, cytotoxicity and nematicidal activities. The present research will provide the needed preliminary observations necessary to select among crude extracts, those with potentially useful properties for further biochemical investigations.

\section{MATERIALS AND METHODS}

Preparation of crude extract

The plant materials, Ferula assafoetida L. (resin), Grewia asiatica L. (leaves), Ipomoea hederacea Jacq. (seeds), Lepidium sativum L. (seeds), and Terminalia chebula Retz. (fruits) were purchased from a local market. These were identified by Dr. Shakeel Ahmad, Bahuddin Zakariya University Multan and a voucher specimen was deposited in the Botany Department of this university. The plant material was air-dried in shade and crushed to a coarse powder separately using mortar and pestle. Plant material $(0.5 \mathrm{~kg}$ each) was macerated with aqueous methanolic mixture $(80: 20 ; \mathrm{v} / \mathrm{v})$, at room temperature for 
fifteen days with occasional shaking. The process was repeated three times with the same quantity of solvent mixture. The extracts so obtained were combined, filtered through filter paper under vacuum and concentrated under reduced pressure in a rotary evaporator (model Q-344B - Quimis, Brazil) using a warm water bath (model Q-214M2 - Quimis, Brazil) to obtain a thick gummy mass, which was further dried in a desiccator and stored in an air-tight vial until further use.

Phytotoxic activity

Phytotoxic activity was determined by using the modified protocol of Lemna minor (Ali et al., 2009; Nisar et al., 2010 b, c). The medium was prepared by mixing various constituents in $100 \mathrm{ml}$ distilled water and the $\mathrm{pH}$ was adjusted (5.5-6.5) by adding $\mathrm{KOH}$ solution. The medium was then autoclaved at 121 ${ }^{\circ} \mathrm{C}$ for 15 minutes. The extracts dissolved in ethanol $(20 \mathrm{mg} /$ $\mathrm{ml}$ ) served as stock solution. Nine sterilized flasks, three for each concentration, were inoculated with $1000 \mu \mathrm{l}, 100 \mu \mathrm{l}$ and $10 \mu \mathrm{l}$ of the stock solution for 500,50 and 5 ppm respectively. The solvent was allowed to evaporate overnight under sterile conditions. To each flask, medium $(20 \mathrm{ml})$ and plants (10), each containing a rosette of three fronds of Lemna minor L., were added. All flasks were plugged with cotton and kept in the growth cabinet for 7 days. The number of fronds per flask were counted and recorded on day seven and their growth regulation in percentage was calculated by the following formula:

Growth regulation $(\%)=$

Mortality $(\%)=\left(\frac{100-\text { Number of fronds in test sample }}{\text { Number of frondsinnegative control }}\right) \times 100$

The result was calculated with reference to the positive and negative control (Table 1). Paraquat was used as a standard drug, while paraquat and volatile solvent were used as positive and negative controls (Nisar et al., 2010 b, c).

\section{Cytotoxic activity}

This activity is an excellent and simple preliminary method to determine the cytotoxicity of crude plant extract and pure natural compounds (Nisar et al., 2010 b, c). In this method, artificial "sea water" was prepared by dissolving 3.8 g sea salt per liter of double distilled water and filtered (Meyer et al., 1982). "Sea water" was placed in a small tank; brine-shrimp eggs were added (1mg) (Artemia salina) and the tank was darkened by covering with aluminum foil. It was allowed to stand for 24 hours at $25{ }^{\circ} \mathrm{C}$, which provided a large number of larvae. Twenty milligrams of the concentrated sample was dissolved in $2 \mathrm{ml} \mathrm{CHCl}_{3}(20 \mathrm{mg} / 2 \mathrm{ml})$ and transferred to 500,50 and $5 \mu \mathrm{l}$ vials corresponding to 1000,100 and $10 \mu \mathrm{g}$ per $\mathrm{ml}$, respectively. Three replicates were prepared for each concentration, making a total of nine vials. The vials containing material were concentrated, dissolved in DMSO $(50 \mu \mathrm{l})$ and $5 \mathrm{ml}$ "sea water" added to each. Then 10 shrimp were added per vial and allowed to stand for 24 hours; then shrimp were counted and the number of surviving shrimp recorded. Etoposide was used as positive control. The data were analyzed with a Finney computer program to determine the $\mathrm{LD}_{50}$ values (Table 2).
Insecticidal activity

Crude extract and all fractions were evaluated against different insects, viz. Tribolium castaneum, Callosbruchus analis, and Rhyzopertha dominica. The test sample was prepared by dissolving $200 \mathrm{mg}$ of crude fractions in $3 \mathrm{ml}$ acetone and loading in Petri dishes covered with filter paper. After 24 hours, 10 test insects were placed in each plate and incubated at $27{ }^{\circ} \mathrm{C}$ for 24 hours with $50 \%$ relative humidity a in growth chamber. The results were analyzed as percentage mortality, calculated with reference to the positive and negative controls (Table 3). Permethrin was used as a standard drug, while permethrin, acetone and test insects were used as positive and negative controls (Ali et al., 2009; Rashid et al., 2009).

The percentage mortality was calculated by the formula:

Growth regulation $(\%)=\left(\frac{\text { Number of in } \mathrm{sec} \text { ts alive in test }}{\text { Number of in } \mathrm{sec} \text { ts alive in control }}\right) \times 100$

TABLE 1

Phytotoxic activity of extracts by Lemna minor bioassay

\begin{tabular}{lccc}
\hline \multicolumn{1}{c}{ Samples } & Conc. & $\begin{array}{c}\text { \% Growth } \\
\text { regulation }\end{array}$ & $\begin{array}{c}\text { Conc. of std. drug } \\
(\mu \mathrm{g} / \mathrm{ml})\end{array}$ \\
\hline F. assafoetida & & 60 & \\
G. asiatica & & 30 & 0.015 \\
I. hederacea & 1000 & 100 & \\
L. sativum & & 64 & \\
T. chebula & & 37 & 0.015 \\
F. assafoetida & & 43 & \\
G. asiatica & & 21 & \\
I. hederacea & 100 & 100 & \\
L. sativum & & 42 & \\
T. chebula & & 30 & 0.015 \\
F. assafoetida & & 30 & \\
G. asiatica & & 17 & \\
I. hederacea & 10 & 80 & \\
L. sativum & & 30 & \\
T. chebula & & 22 & \\
\hline
\end{tabular}

TABLE 2

Cytotoxic activity of extracts by brine shrimp lethality bioassay

\begin{tabular}{lcccc}
\hline \multirow{2}{*}{ Sample } & \multicolumn{3}{c}{$\%$ deaths at doses } & \multirow{2}{*}{ DD $_{50}$} \\
\cline { 2 - 5 } & $\begin{array}{c}1000 \mu \mathrm{g} / \\
\mathrm{ml}\end{array}$ & $\begin{array}{c}100 \mu \mathrm{g} / \\
\mathrm{ml}\end{array}$ & $10 \mu \mathrm{g} / \mathrm{ml}$ & \\
\hline F. assafoetida & 50 & 40 & 25 & 310.3220 \\
G. asiatica & 26 & 25 & 22 & 41389.2 \\
I. hederacea & 100 & 100 & 70 & 0.0332 \\
L. sativum & 60 & 48 & 28 & 262.4612 \\
T. chebula & 26 & 24 & 22 & 346568.9 \\
Etoposide (standard) & & & & 7.4625 \\
\hline
\end{tabular}




\section{Nematicidal activity}

For isolation of Helicotylenchus indicus nematodes, $500 \mathrm{mg}$ of soil samples (depth 15-25 cm) were collected from rice paddy (Oryza sativa L.) fields. Soil samples were processed by Cobb sieving (Cobb, 1918) and a modified Baermann funnel method (Baermann, 1917). The soil sample was put into a large bucket containing water and the mixture was vigorously stirred into a suspension, which was allowed to settle for about 2 minutes. The heavy soil particles sank to the bottom but nematodes remained suspended in the water. The remaining suspension was slowly poured over a coarse sieve (60 mesh aperture), which was continuously tapped by hand to avoid blocking. The deposit on the sieve was washed with a gentle jet of water into a beaker. This water suspension, containing eel-shaped nematodes, was passed through 200 and 300 mesh sieves. The nematodes thus recovered were mixed and water was decanted after allowing sufficient time for the nematodes to settle down. Then the nematode suspension was poured over a piece of tissue paper attached to a perforated plastic sheet placed in a funnel fitted with a rubber tube and clamped at the lower end. The water contained in the funnel barely touched the bottom of the tissue paper. Care was taken not to allow the debris to float off the edges of the tissue paper. After 24 hours the nematodes wriggled out into the clear water in the funnel and settled at the bottom, and then $100 \mathrm{ml}$ of water containing the nematodes was drawn into a beaker. The nematode suspension was allowed to settle for 2 hours or more, the excess supernatant water was poured off, and the remaining concentrated content was transferred into a cavity block for examination under a stereomicroscope and selecting nematodes (Naqvi et al., 1992). Crude extracts were dissolved in water (passed through Whatman filter paper No.1) to make dilutions of $2 \%, 1 \%, 0.5 \%$, and $0.25 \%$. Experiments were performed under laboratory conditions at $28 \pm 2{ }^{\circ} \mathrm{C}$. Glass tubes $15 \mathrm{~cm}$ long and $8 \mathrm{~cm}$ were used for bioassay. Three $\mathrm{ml}$ were taken from all dilutions in each tube. The required amount of nematode suspension (100 freshly hatched second stage juveniles $/ 3 \mathrm{ml}$ suspension) was poured into tubes to each of which an equal amount of plant extract had already been poured). Distilled water with nematode larvae was taken as control. The dead nematodes were observed under a stereoscopic binocular microscope after 2448 and 72 hours and percentage mortality was calculated (Table 4). Nematodes were considered dead if they did not move when probed with a fine needle (Cayrol et al., 1989).

\section{Larvicidal activity}

The infective L3 larvae of Haemonchus contortus were obtained by culturing fecal samples directly from the rumen of the sheep naturally infected by mixed gastrointestinal nematodes. L3 Larvae were incubated with the plant extracts used at concentrations of $50,25,12.5,6.25$ and $3.12 \mathrm{mg} / \mathrm{ml}$ of saline phosphate buffer (Ph 7.2). Ivermectin was used as standard. Mortality of the larvae subjected to the above treatments was used as the criterion for anthelmintic activity. Motility was recorded at 0, 1, 2, 3, 4, and 8 hour intervals (Iqbal et al., 2004). $\mathrm{LC}_{50}$ was determined using regression analysis and solving the regression equation (Table 5).

\section{RESULTS AND DISCUSSION}

With a rich endemic flora, Pakistan has many plant species which are not yet explored; detailed compendia of medicinal species native to Pakistan are being published. Strategies like high-throughput screening, phytochemical profiling, quality controls and standardization of raw materials and finished products, clinical trials and herbal therapeutics will lead to maximum benefits from these plants. The compiled data will be helpful for chemotaxonomy and breeding, as well as authenticity testing of phytopharmaceuticals containing these extracts.

Phytotoxic results of crude extracts of selected plants are shown in Table 1. The criteria used for phytotoxicity were as follows: $0-39 \%$ inhibition (low activity), 40-59\% inhibition (moderate activity), 60-69\% inhibition (good activity),

TABLE 3

Insecticidal activity of of extracts against various insects

\begin{tabular}{lccc}
\hline \multirow{2}{*}{ Samples } & \multicolumn{3}{c}{$\%$ Mortality } \\
\cline { 2 - 4 } & C. analis & T.castaneum & R. dominica \\
\hline F. assafoetida & 30 & 30 & 25 \\
G. asiatica & 20 & 20 & 20 \\
I. hederacea & 80 & 70 & 75 \\
L. sativum & 70 & 65 & 70 \\
T. chebula & 50 & 50 & 45 \\
\hline
\end{tabular}

\section{TABLE 4}

Nematicidal activity of extracts against Helicotylenchus indicus

\begin{tabular}{lccccccc}
\hline \multirow{2}{*}{ Samples } & \multicolumn{6}{c}{$\%$ Mortality observed against concentration } \\
\cline { 2 - 7 } & \multicolumn{3}{c}{$\mathbf{2 4} \mathbf{~ h r}$} & \multicolumn{5}{c}{$\mathbf{4 8} \mathbf{~ h r}$} & Control \\
\cline { 2 - 6 } & $\mathbf{2}$ & $\mathbf{1}$ & $\mathbf{0 . 5}$ & $\mathbf{2}$ & $\mathbf{1}$ & $\mathbf{0 . 5}$ & \\
\hline F. assafoetida & 49 & 31 & 25 & 57 & 45 & 37 & 1 \\
G. asiatica & 22 & 17 & 10 & 39 & 23 & 20 & 1 \\
I. hederacea & 90 & 65 & 55 & 96 & 82 & 58 & 2 \\
L. sativum & 63 & 48 & 28 & 69 & 55 & 33 & 2 \\
T. chebula & 40 & 29 & 15 & 52 & 39 & 24 & 2 \\
\hline
\end{tabular}

TABLE 5

Larvicidal activity $\left(\mathrm{LC}_{50} \mathrm{mg} / \mathrm{ml}\right)$ of extracts against Haemonchus contortus

\begin{tabular}{lc}
\hline \multicolumn{1}{c}{ Samples } & Larvicidal Activity $\left(\mathrm{LC}_{50}\right)$ \\
\hline F. assafoetida & 9.11 \\
G. asiatica & 17.21 \\
I. hederacea & 2.07 \\
L. sativum & 6.52 \\
T. chebula & 4.82 \\
Ivermectin (standard ) & 3.19 \\
\hline
\end{tabular}


above $70 \%$ inhibition (significant activity). Ipomoea hederacea appeared to have very significant phytotoxic activity, with $100 \%$ inhibition of Lemna minor growth at high concentrations (1000 and $100 \mu \mathrm{g} / \mathrm{mL}$ ). Ferula assafoetida and Lepidium sativum showed a good response (60-64\%) at a concentration of 1000 $\mu \mathrm{g} / \mathrm{mL}$. Grewia asiatica and Terminalia chebula showed low weedicidal activity (30-37\%) at a concentration of $1000 \mu \mathrm{g} / \mathrm{mL}$. The data suggests the potential of Ipomoea hederacea for further phytochemical analysis as a potent herbicide. Interference of weeds obviously reduces the quality and quantity of agricultural crops and is responsible for huge economic losses all over the world. Synthetic herbicides are extensively used for the control of weeds in agricultural sectors. However, various factors that restrict the use of synthetic herbicides include water and soil pollution, herbicide-resistant weed populations, herbicide residues and detrimental effects on non-target species. In recent times, more emphasis has been placed on natural allelochemicals from plants for weed control in crop production especially to cope with the problem of weed resistance (Li et al., 2003; Saeed et al., 2010).

Cytotoxicity of crude extracts of selected plants is shown in Table 2. Ipomoea hederacea exhibited significant cytotoxic effect at high concentrations of 1000 and $100 \mu \mathrm{g} / \mathrm{mL}$. G. asiatica and T. chebula exhibited weak lethality, with $\mathrm{LD}_{50}$ values of 41389.2 and $346568.9 \mu \mathrm{g} / \mathrm{mL}$, respectively. Ferula assafoetida and Lepidium sativum showed a moderate response, with 50$60 \%$ deaths at a concentration of $1000 \mu \mathrm{g} / \mathrm{mL}$. This test is used as litmus test for presence of anticancer compounds. Our results suggest the presence of natural anticancer products in Ipomoea hederacea seed extract. Our results are supported by recent findings of Parekh (Parekh et al., 2012) which proved anticancerous activity of Ipomoea hederacea seed extract.

Insects control relies heavily on the use of synthetic insecticides; however, their widespread use has led to various problems such as the development of insect strains resistant to insecticides (Zettler and Cuperus, 1990; White, 1995; Ribeiro et al., 2003), toxic residues on stored grain, toxicity to consumers and increasing costs of application. There is an urgent need to develop safe alternatives that are of low cost, convenient to use and environmentally friendly. Insecticidal results of investigated plant extracts are shown in Table 3 . The results indicated that Ipomoea hederacea and Lepidium sativum seed extracts showed the highest insecticidal activity against all three insects, while the remaining extracts had moderate to average activity against all insects.

Nematodes are pathogens which cause serious damage to agricultural crops and plants. These nematodes may be controlled by synthetic nematicides. However, environmental and human health concerns are resulting in increased restrictions on use of synthetic nematicides. Some safe procedures for nematode control have been developed based on biological control agents and organic amendments (Noling and Becker, 1994); one of them is use of plant extracts against these nematodes. This method has drawn great interest from researchers in the prevention of nematodes due to the environmental pollution problems induced by synthetic nematicides. Three different concentrations were used; $2 \%$, $1 \%$ and $0.5 \%$ with examination after 24 and 48 hours. The results (Table 4) indicated that Ipomoea hederacea seed extract exhibited very strong nematicidal capacity against $H$. indicus. Ferula assafoetida has shown activity against Pheretima posthuma (Naikwadi and Bhalodia, 2009).
The $\mathrm{LC}_{50}$ value for methanolic extracts against Haemonchus contortus are presented in Table 5. The results indicate that $L$. sativum and $T$. chebula and $I$. hederacea have significant anthelmintic activity. The greatst anthelmintic activity was shown by $I$. hederacea, whose $\mathrm{LC}_{50}$ was $2.07 \mathrm{mg} / \mathrm{ml}$ and the lowest was observed for G. asiatica, $17.21 \mathrm{mg} / \mathrm{ml}$. Haemonchus contortus is responsible for severe economic losses in sheep and goat breeding globally. The results confirm the traditional use of L. sativum and T. chebula for anthelmintic purposes (Abbas et al., 2002; Kamaraj and Rahuman, 2011).

The results clearly indicated that all activities are dose dependent, i.e. high activity at high concentrations and vice versa. The possible action of plant extracts is attributed to the bioactive compounds present as secondary metabolites in the form of condensed tannins, saponins, polyphenols, and flavonoids. Chemical analyses and biological and pharmacological assays provide objective evidence to validate traditional uses by indigenous communities. Further, to export herbs it is necessary to put them into value-added products. The current study will open avenues for future in depth research on these plants.

\section{ACKNOWLEDGEMENTS}

Authors are highly thankful to Mussarat Akhter of PCSIR Labs Complex, Karachi for her help in carrying out nematicidal activities.

\section{REFERENCES}

ABBAS B, AL-QARAWI AA, AL-HAWAS A (2002). The ethnoveterinary knowledge and practice of traditional healers in Qassim Region, Saudi Arabia. J. Arid Environ., 50: 367-379.

ALI I, RUBINA N, WAHIB NK, RUKHSANA G, CHOUDHARY MI (2009). Biological screening of different root extracts of Euphorbia wallichii. Pak. J. Bot., $41:$ 1737-1741.

BAERMANN G (1917). Eine einfache Methode zur Auffindung von Ankylostomum (Nematoden)-Larven in Erdproben. Welteureden. Batavia. Geneesk. Tijschr Ned Ind., 57: 131-137.

CARYROL JC, DJIAN C, PIJAROWSKI I (1989). Studies on the nematicidal properties of the culture filtrate of the nematophagous fungus Pacilomyces lilacinus. Rev Nematol, 12: 331-336.

CHOPRA RN, NAYAR SL, CHOPRA IC (1986). Glossary of Indian Medicinal Plants (Including the Supplement). Council of Scientific and Industrial Research, New Delhi, India.

COBB NA (1918). Estimating the nema population of soil. Agric Tech Circ US Deptt Agric., 1: 4.

FINNY DJ (1971). Probit Analysis. $3^{\text {rd }}$ edition, Cambridge University Press, Cambridge, pp. 333.

IQBAL Z, LATEEF M, ASHRAF M, JABBAR A (2004). Anthelmintic activity of Artemisia brevifolia in sheep. J Ethnopharm., 93, 265-268.

JOSHI SG (2000). Medicinal plants. Oxford and IBH Publishing Co. Ltd, Jan Paths, New Delhi, India.

KAMARAJ C, RAHUMAN AA (2011).Efficacy of anthelmintic properties of medicinal plant extracts against Haemonchus contortus. Res. Vet. Sci., 91,400-404.

LI Y, SUN Z, ZHUANG X, XU L, CHEN S, LI M (2003).Research progresson microbial herbicides. Crop Prot., 22: 247-252.

MANOHAR D, VISWANATHA GL, NAGESH S, JAIN V, SHIVAPRASAD HN (2012).Ethnopharmacology of Lepidium Sativum Linn (Brassicaceae): A Review. Int. J. Phyto. Res., 2:1-7.

MEYER NB, FERRIGNI RN, PUTNAM EJ, JACOBSEN BL, NICHOLS ED, MCLAUGHLIN IJ (1982). Brine shrimp: A convenient general bioassay for active plant constituents. Planta Med., 45: 31-35.

NADKARNI AK (1976). Terminalia chebula In: Nadkarni's Indian Materia Madica, 3rd Edn. Bombay: Popular Prakashan Pvt. Ltd.

NAIKWADI VG, BHALODIA KG (2009). In vitro comparative anthelmintic property of crude drug's from mineral and herbal origin with albendazole. Int. J. Pharm. Res. Dev., 1:7-9. 
NASIR E, ALI SI (1979). Flora of West Pakistan. Shamim Printing Press Karachi, Pakistan.

NAQVI BS, KHAN A, SHAIKH D, SHAIKH MR (1992). Nematicidal properties of selected marine algae from Karachi coast. J. Islam. Acad. Sci., 5: 171-172.

NISAR M, QAYUM M, SHAH MR, KALEEM WA, ALI I, ZIA-UL-HAQ M (2010a). Antimicrobial screening of Impatiens bicolor Royle. Pak. J. Bot., 42: 523-526.

NISAR M, QAYUM M, SHAH MR, SIDDIQUI HL, KALEEM WA, ZIA-ULHAQ M (2010b). Biological screening of Impatiens bicolor Royle. Pak. J. Bot., 42: 1903-1907.

NISAR M, KALEEM WA, QAYUM M, HUSSAIN A, ZIA-UL-HAQ M, ALI I, CHOUDHARY MI (2010c). Biological screening of Zizyphus oxyphylla Edgew leaves. Pak. J. Bot., 42: 4063-4069.

NISAR M, KALEEM WA, QAYUM M, MARWAT IK, ZIA-UL-HAQ M, ALI I, CHOUDHARY MI (2011). Biological screening of Zizyphus oxyphylla Edgew stem. Pak. J. Bot., 43:311-317.

NOLING JW, BECKER JO (1994). The challenge of research and extension to define and implement alternatives to methyl bromide. J. Nematol., 26: 573-586.

PAREKH KK, PATEL AM, MODI AJ, CHANDRASHEKHAR HR (2012). Antioxidant and cytotoxic activities of few selected Ipomoea species. Pharm., 3: 377-386.

RIEBEIRO BM, GUEDES RNC, OLIVEIRA EE, SANTOS JP (2003). Insecticide resistance and synergism in Brasilian populations of Sitophilus zeamais (Coleoptera: Curculionidae). J. Stored Prod. Res., 39: 21-31

SAEED M, KHAN H, KHAN MA, SIMJEE SU, MUHAMMAD N, KHAN SA (2010). Phytotoxic, insecticidal and leishmanicidal activities of aerial parts of Polygonatum verticillatum. Afri. J. Biotech., 9: 1241-1244.

WHITE NDG (1995). Insects, mites, and insecticides in stored grain ecosystems. In: Jayas DS, White ND, Muir WE (Eds.), Stored Grain Ecosystem. Marcel Dekker, NY. U.S.A, pp 123-168.

ZETTLER JL, CUPERUS GW (1990). Pesticide resistance in Tribolium castaneum (Coleopteran: Tenebrionidae) and Rhyzopertha dominica (Coleoptera: Bostrichidae) in wheat. J. Econ. Entomol., 83: 1677-1681.

ZIA-UL-HAQ M, IQBAL S, AHMAD M (2008a). Characteristics of oil from seeds of 4 mungbean (Vigna radiate L. wilczek) cultivars grown in Pakistan. J. Am. Oil Chem. Soc., 85: 851-856.

ZIA-UL-HAQ M, IQBAL S, AHMAD S, BHANGER MI, WICZKOWSKI W, AMAROWICZ R (2008b). Antioxidant Potential of Desi Chickpea varieties commonly consumed in Pakistan. J. Food Lipid., 15: 26-342.
ZIA-UL-HAQ M, AHMAD S, AHMAD M, IQBAL S, KHAWAR KM (2009). Effects of cultivar and row spacing on tocopherol and sterol composition of chickpea (Cicer arietinum L) seed oil. Tarim Bilimleri Dergisi, 15: 25-30.

ZIA-UL-HAQ M, AHMAD S, CHIAVARO E, MEHJABEEN, AHMED S (2010). Studies of oil from cowpea (Vigna unguiculata (1) walp.) cultivars commonly grown in Pakistan. Pak. J. Bot., 42(2): 1333-1341.

ZIA-UL-HAQ M, AHMAD S, SHAD MA, IQBAL S, QAYUM M, AHMAD A, LUTHRIA DL, AMAROWICZ R (2011a). Compositional studies of some of lentil cultivars commonly consumed in Pakistan. Pak. J. Bot., 43(3): 1563-1567.

ZIA-UL-HAQ M, AHMAD M, MEHJABEEN, JEHAN N, AHMAD S, QAYUM M, MARWAT IK (2011b). Antimicrobial screening of selected flora of Pakistan. Arch. Biol. Sci., 63(3): 691-695.

ZIA-UL-HAO M, NISAR M, SHAH MR, AKHTER M, OAYUM M, AHMAD S, SHAHID SA, HASANUZZAMAN M (2011C).Toxicological screening of some selected legumes seed extracts. Leg. Res., 34: 242-250.

ZIA-UL-HAQ M, ĆAVAR S, QAYUM M, IMRAN I, DEFEO V (2011d). Compositional studies: antioxidant and antidiabetic activities of Capparis decidua (Forsk.) Edgew. Int. J. Mol. Sci., 12: 8846-8861.

ZIA-UL-HAO M, AHMAD S, IOBAL S, LUTHRIA DL, AMAROWICZ R (2011e). Antioxidant potential of lentil cultivars commonly consumed in Pakistan. Oxid. Comm., 34:819-831.

ZIA-UL-HAQ M, SHAHID SA, AHMED S, AHMAD S, QAYUM M, KHAN I (2012a). Anti-platelet activity of methanolic extract of Grewia asiatica L. leaves and Terminalla chebula Retz. fruits. J. Med. Plants Res., 6(10): 2029-2032.

ZIA-UL-HAQ M, KAUSAR A, SHAHID SA, QAYUM M, AHMAD S, KHAN I (2012b). Phytopharmacological profile of Gratiola officinalis Linn., A review. J. Med. Plants Res., 6 (16): 3087-3092.

ZIA-UL-HAQ M, SHAHID SA, AHMAD S, QAYUM M, KHAN I (2012c). Antimalarial, antiemetic and antidiabetic potential of Grewia asiatica L. leaves. J. Med. Plants Res., 6 (16): 3213-3216.

ZIA-UL-HAQ M, SHAHID SA, AHMAD S, QAYUM M, KHAN I (2012d). Antioxidant potential of various parts of Ferula assafoetida L. J. Med. Plants Res., 6(16):3254-3258.

ZIA-UL-HAQ M, KHAN BA, LANDA P, KUTIL Z, AHMED S, QAYUM M, AHMAD S (2012e). Platelet aggregation and anti-inflammatory effects of garden pea, desi chickpea and kabuli chickpea. Acta Pol. Pharm., 69 (4):707-711.

ZIA-UL-HAQ M, SHAHID SA, KHAN BA, IMRAN I, QAYUM M, AKHTER M, KHAN Z, MUHAMMAD S (2012f). Nematicidal potential of selected flora of Pakistan. J. Med. Plants Res., 6(24): 4087-4090. 
